\title{
Airway and alveolar nitric oxide production, lung function, and pulmonary blood flow in sickle cell disease
}

\author{
Alan Lunt ${ }^{1,2}$, Na'eem Ahmed', Gerrard F. Rafferty', Moira Dick ${ }^{3}$, David Rees ${ }^{3,4}$, Sue Height ${ }^{3}$, Swee Lay Thein ${ }^{3,4}$ and \\ Anne Greenough ${ }^{1,2}$
}

\begin{abstract}
BACKGROUND: Children with sickle cell disease (SCD) often have obstructive lung function abnormalities which could be due to asthma or increased pulmonary blood volume; it is important to determine the underlying mechanism to direct appropriate treatment. In asthmatics, exhaled nitric oxide $\left(\mathrm{F}_{\text {eNO }}\right)$ is elevated. $F_{\text {eNo, }}$, however, can also be raised due to increased alveolar production. Our aim, therefore, was to determine if airway or alveolar NO production differed between SCD children and ethnic and age-matched controls.
\end{abstract}

METHODS: Lung function, airway NO flux and alveolar NO production, and effective pulmonary blood flow were assessed in 18 SCD children and 18 ethnic and age-matched controls.

RESULTS: The SCD children compared to the controls had a higher respiratory system resistance $(P=0.0008)$, alveolar NO production $(P=0.0224)$, and pulmonary blood flow $(P<0.0001)$, but not airway NO flux. There was no significant correlation between $\mathrm{F}_{\mathrm{eNO}}$ and respiratory system resistance in either group, but in the SCD children, there were correlations between alveolar NO production $(P=0.0006)$ and concentration $(P<0.0001)$ and pulmonary blood flow.

CONCLUSION: Airway NO flux was not elevated in the SCD children nor correlated with airways obstruction, suggesting that airways obstruction, at least in some SCD children, is not due to asthma.

$\mathrm{t}$ is estimated that approximately 250,000 children are born with sickle cell disease (SCD) each year (1). The majority of children with SCD in developed countries can expect to survive to adulthood (2) but may then suffer severe morbidity including chronic hypoxia and pulmonary hypertension (3). Whereas restrictive lung function abnormalities are common in adults, obstructive lung function abnormalities are more frequently reported in children (4), but the etiology of the latter remains unclear. It is possible that the obstructive lung function abnormalities may be due to asthma. An increased prevalence of asthma was reported in one study of SCD children (5), but other studies have indicated a similar incidence to that of non-SCD populations $(6,7)$. Another explanation for the airways obstruction in SCD is the hyperdynamic pulmonary circulation due to a raised cardiac output resulting from chronic anemia (8). In children with SCD, we have demonstrated that pulmonary capillary blood volume is increased compared to matched controls and correlated with airflow obstruction (9). In a study of vascular abnormalities on high-resolution computed tomography scanning, we used two quantitative measures to assess vessel dilatation (the segmental artery-bronchus $(\mathrm{A} / \mathrm{B})$ ratio and the total cross-sectional area of all pulmonary vessels less than $5 \mathrm{~mm}$ in diameter (cross-sectional area $<5 \mathrm{~mm} \%)$ ) (10). Increases in segmental A/B ratio and cross-sectional area $<5 \mathrm{~mm} \%$ were independently linked to reductions in forced expiratory volume in $1 \mathrm{~s}\left(\mathrm{FEV}_{1}\right)$, vital capacity (VC), and forced expiratory flow between 25 and 75\% of $\mathrm{VC}$ exhaled $\left(\mathrm{FEF}_{25-75}\right)$ and to increased respiratory system resistance and residual volume:total lung capacity (RV:TLC). Furthermore, small vessel dimensions correlated with reduced hemoglobin concentration and increased cardiac output (10). Those data suggest that the obstructive lung function abnormalities were related to a hyperdynamic circulation.

Measurement of exhaled nitric oxide $\left(\mathrm{F}_{\mathrm{eNO}}\right)$, which is elevated in asthma due to enhanced expression of inducible nitric oxide synthase in inflamed airways, might help to further elucidate whether asthma is increased in SCD children. In one study, $\mathrm{F}_{\text {eNO }}$ was reduced in SCD patients (11), a possible explanation is reduced nitric oxide (NO) bioavailability resulting from chronic hemolysis and NO scavenging by the cell free hemoglobin (12). A reduced $\mathrm{F}_{\mathrm{eNO}}$, however, has not been found in other cohorts $(13,14) . \mathrm{F}_{\mathrm{eNO}}$ has also been shown to be elevated in patients with atrial septal defects or liver cirrhosis. Both conditions are associated with a hyperdynamic pulmonary circulation and $\mathrm{F}_{\mathrm{eNO}}$ correlated with increased pulmonary blood flow $(15,16)$. In patients with liver cirrhosis, the enhanced NO output was shown to be of alveolar and not airway origin (17). Whether the hyperdynamic circulation in SCD patients (8) influences their $\mathrm{F}_{\mathrm{eNO}}$ levels has not been investigated.

In individuals with $\mathrm{SCD}, \mathrm{F}_{\text {eNO }}$ has been previously measured at a single fixed exhalation flow of $50 \mathrm{ml} / \mathrm{s}(11,13)$ but measurements at multiple exhalation flows allow partitioning into

'Division of Asthma, Allergy and Lung Biology, MRC Centre for Allergic Mechanisms in Asthma, King's College London, London, UK; ${ }^{2}$ National Institute for Health Research Biomedical Research Centre based at Guy's and St Thomas' NHS Foundation Trust and King's College London, London, UK; ${ }^{3}$ Department of Haematology, King's College Hospital NHS Foundation Trust, London, UK; ${ }^{4}$ Division of Cancer Studies, King's College London, London, UK. Correspondence: Anne Greenough (anne.greenough@kcl.ac.uk) Received 28 May 2015; accepted 4 August 2015; advance online publication 2 December 2015. doi:10.1038/pr.2015.217 
flow-independent airway and alveolar components $(18,19)$. Using such a technique, SCD children were found to have an elevated airway nitric NO flux, but the alveolar NO concentration did not differ significantly from that found in healthy controls (14). A limitation of that study (14), however, was that the children in the control group were not matched for race and ethnic differences have been reported for $\mathrm{F}_{\mathrm{eNO}}$ indices (20-22). Furthermore, as the transfer factor for NO (DLNO) was not measured (14), it was not possible from those results to determine whether any elevation might be due to passive accumulation due to gas exchange impairment or reflected increase in alveolar production. Thus, it is important that flow-independent $\mathrm{F}_{\text {eNO }}$ parameters obtained using the multiple exhalation flow technique are measured in SCD patients and compared with appropriately matched controls to reliably determine whether or not $\mathrm{F}_{\mathrm{eNO}}$ is elevated in SCD children and whether any elevation of $\mathrm{F}_{\mathrm{eNO}}$ is due to increased airway NO flux or to increased alveolar NO production due to a hyperdynamic pulmonary circulation.

We, therefore, aimed to determine if airway NO flux and alveolar NO production differed between children with SCD and ethnic-matched controls and whether airway NO flux correlated with airways obstruction and alveolar NO production to a hyperdynamic pulmonary circulation. Such data would inform the debate as to whether airways obstruction in SCD is due to asthma and hence treatment strategies.

\section{RESULTS}

\section{Subjects}

Eighteen children with SCD and 18 controls were assessed. The SCD children and the controls were of similar age and sex (Table 1). Two patients with SCD and one control had a physician diagnosis of asthma. One of the SCD patients with asthma was receiving inhaled corticosteroids. Nine SCD children had a history of acute chest syndrome and five were on hydroxyurea therapy; none were undergoing regular blood transfusions.

\section{Lung Function, $\mathrm{F}_{\mathrm{eNO}^{\prime}}$ and Effective Pulmonary Blood Flow}

The SCD children compared to the controls had a significantly lower FEV $1(P<0.0001)$, VC $(P<0.0001), \mathrm{FEF}_{25-75}(P=0.0071)$, $\mathrm{FEV}_{1}: \mathrm{VC}(P=0.0315)$, TLC $(P=0.0024)$, and $\mathrm{SpO}_{2}(P=0.0023)$ and a significantly higher $\mathrm{R}_{5}(P=0.0008)$ and $\mathrm{K}_{\mathrm{CO}}(P=0.0114)$ (Table 1). In the SCD group, three patients $(17 \%)$ had restrictive, two obstructive (11\%), and two mixed (11\%) ventilatory defects. Three SCD patients (17\%) had an isolated reduction in DLCO. None of the controls had a restrictive defect and one had an obstructive pattern. One control had an isolated reduction in DLCO.

There were no significant differences between the groups with regard to $\mathrm{F}_{\mathrm{eNO}, 50 \mathrm{~m} / \mathrm{s}}$ or total maximal airway NO flux $\left(\mathrm{J}_{\mathrm{aw}, \mathrm{NO}}^{\prime}\right)$ (Table 2). Compared to the control group, the SCD patients had a significantly higher alveolar NO concentration $\left(\mathrm{C}_{\mathrm{A}, \mathrm{NO}}\right)(P=0.0007)$, rate of alveolar $\mathrm{NO}$ production $\left(\mathrm{V}_{\mathrm{A}, \mathrm{NO}}\right)$ $(P=0.0224)$, effective pulmonary blood flow $\left(\mathrm{Q}_{\mathrm{pulm}}\right)(P=0.0006)$, and pulmonary blood flow index $\left(\mathrm{Q}_{\text {pulm }}\right)(P<0.0001)$.
Table 1. Demographics and lung function by sickle cell disease status

\begin{tabular}{|c|c|c|c|}
\hline & $\begin{array}{l}\text { Sickle cell disease } \\
\text { children }\end{array}$ & Controls & \\
\hline$N$ & 18 & $n=18$ & $P$ value \\
\hline Sex (female $n(\%)$ ) & $9(50 \%)$ & $9(50 \%)$ & 1.0000 \\
\hline Age (years) & $16.0(9-18)$ & $17.0(11-18)$ & 0.2310 \\
\hline$[\mathrm{Hb}](\mathrm{g} / \mathrm{dl})$ & $8.3(6.0-10.3)$ & - & - \\
\hline $\mathrm{FEV}_{1}$ & 79.1(47.5-105.8) & $104.5(78.6-124.5)$ & $<0.0001$ \\
\hline VC & $85.1(48.6-107.8)$ & $107.5(80.2-125.6)$ & $<0.0001$ \\
\hline $\mathrm{FEF}_{25-75}$ & $58.5(29.2-138.2)$ & $92.4(53.5-153.9)$ & 0.0071 \\
\hline $\mathrm{FEV}_{1}: \mathrm{VC}$ & $91.0(75.2-104.5)$ & $98.8(87.3-112.1)$ & 0.0315 \\
\hline TLC & $83.1(73.8-106.5)$ & $102.5(85.5-125.3)$ & 0.0024 \\
\hline RV & $85.1(31.8-125.3)$ & 93.0(58.11-155.3) & 0.1461 \\
\hline $\mathrm{D}_{\mathrm{L}} \mathrm{CO}$ & $88.5(65.0-122.0)$ & $87.1(66.1-127.7)$ & 0.5841 \\
\hline $\mathrm{K}_{\mathrm{co}}$ & $97.4(70.0-132.0)$ & $86.1(69.0-115.1)$ & 0.0114 \\
\hline $\mathrm{R}_{5}$ & $145.6(107.8-234.1)$ & 111.7(67.2-168.6) & 0.0008 \\
\hline $\mathrm{SpO} 2^{*}(\%)$ & 95 (89-99) & 98(96-99) & 0.0023 \\
\hline $\begin{array}{l}\mathrm{D}_{\mathrm{L}} \mathrm{NO}^{*} \\
\text { (in } \mathrm{ml} / \mathrm{min} / \mathrm{mHg} \text { ) }\end{array}$ & $62.7(37.9-83.8)$ & $85.3(44.3-113.3)$ & 0.0002 \\
\hline
\end{tabular}

Results are presented as median (range) and the lung function data expressed as a percentage of the predicted value unless otherwise indicated*. -indicate that data were not measured.

FEV , forced expiratory volume in $1 \mathrm{~s}$; RV, residual volume; TLC, total lung capacity; VC, vital capacity.

Table 2. $F_{\text {eNO }}$ and pulmonary blood flow measurements

\begin{tabular}{lcccc}
\hline & $\begin{array}{c}\text { Sickle cell disease } \\
\text { children }\end{array}$ & & Controls & \\
\cline { 2 - 2 }$N$ & 18 & & 18 & Pvalue \\
\hline $\mathrm{F}_{\mathrm{eNO}, 50 \mathrm{~m} / \mathrm{s}}$ & $14.7(1.6-92.3)$ & & $14.6(1.2-56.1)$ & 0.7569 \\
$\mathrm{~J}^{\prime}{ }_{\mathrm{aw}, \mathrm{NO}}$ & $33.5(6.1-403.6)$ & & $60.8(1.4-319.1)$ & 0.3038 \\
$\mathrm{C}_{\mathrm{A}, \mathrm{NO}}$ & $7.0(1.3-7.3)$ & & $2.5(0.6-5.9)$ & 0.0007 \\
$\mathrm{~V}_{\mathrm{A}, \mathrm{NO}}^{\prime}$ & $319.0(57.3-663.7)$ & & $151.0(31.8-447.1)$ & 0.0224 \\
$\mathrm{Q}_{\text {pulm }}$ & $7.80(4.25-10.85)$ & & $5.50(3.55-7.70)$ & 0.0006 \\
$\mathrm{Q}_{\text {pulm }}$ & $4.97(3.77-6.82)$ & $3.29(2.48-4.50)$ & $<0.0001$ \\
\hline
\end{tabular}

In the SCD children and the controls, no significant correlations were observed between $\mathrm{F}_{\text {eNO }}$ indices and $\mathrm{R}_{5}$ or $\mathrm{FEV}_{1}: \mathrm{VC}$ (Table 3). In the SCD group, $\mathrm{Q}_{\text {pulm }}$ was positively correlated with $\mathrm{F}_{\mathrm{eNO}, 50 \mathrm{~m} / \mathrm{s}}(P=0.036), \mathrm{C}_{\mathrm{A}, \mathrm{NO}}(P=0.0343)$, and $\mathrm{V}_{\mathrm{A}, \mathrm{NO}}(P=0.0002)$ (Table 4). QI $\mathrm{I}_{\text {pulm }}$ was positively correlated with $\mathrm{F}_{\mathrm{eNO}}(r=0.591$, $P=0.0112), \mathrm{C}_{\mathrm{A}, \mathrm{NO}}(r=0.742, P=0.0006)$, and $\mathrm{V}_{\mathrm{A}, \mathrm{NO}}(r=0.806$, $P<0.0001$ ) (Figure 1). No significant correlations were seen between $\mathrm{F}_{\mathrm{eNO}}$ indices and $\mathrm{Q}_{\text {pulm }}$ or $\mathrm{QI}_{\text {pulm }}$ in the control group (Table 4). In the SCD children, hemoglobin concentration was correlated with QIpulm $(r=-0.56, P=0.0157)$ and alveolar NO concentration $(r=-0.46, P=0.0488)$.

\section{DISCUSSION}

We have demonstrated that children with SCD compared to controls had an elevated alveolar nitric oxide concentration and increased alveolar production, but their maximal airway 
Table 3. Correlations between $\mathrm{F}_{\mathrm{eNO}}$ and airflow obstruction assessment

\begin{tabular}{|c|c|c|c|}
\hline \multicolumn{4}{|c|}{ Sickle cell disease children } \\
\hline & & $R$ & $P$ \\
\hline $\mathrm{F}_{\mathrm{eNO}, 50 / / \mathrm{s}}$ & $\mathrm{FEV}_{1}: \mathrm{VC}$ & -0.340 & 0.1681 \\
\hline $\mathrm{F}_{\mathrm{eNO}, 50 / / \mathrm{s}}$ & R5 & 0.286 & 0.2493 \\
\hline$J^{\prime}{ }_{a w, N O}$ & $\mathrm{FEV}_{1}: \mathrm{VC}$ & -0.161 & 0.5139 \\
\hline $\mathrm{J}_{\mathrm{aw}, \mathrm{NO}}^{\prime}$ & R5 & 0.420 & 0.0840 \\
\hline $\mathrm{C}_{\mathrm{A}, \mathrm{NO}}$ & $\mathrm{FEV}_{1}: \mathrm{VC}$ & -0.179 & 0.4769 \\
\hline$C_{A, N O}$ & R5 & -0.214 & 0.3931 \\
\hline \multicolumn{4}{|c|}{ Controls } \\
\hline $\mathrm{F}_{\mathrm{eNO}, 50 / \mathrm{s}}$ & $\mathrm{FEV}_{1}: \mathrm{VC}$ & -0.311 & 0.2234 \\
\hline $\mathrm{F}_{\mathrm{eNO}, 501 / \mathrm{s}}$ & R5 & -0.245 & 0.3417 \\
\hline $\mathrm{J}_{\mathrm{aw}, \mathrm{NO}}^{\prime}$ & $\mathrm{FEV}_{1}: \mathrm{VC}$ & -0.220 & 0.3805 \\
\hline $\mathrm{J}_{\mathrm{aw}, \mathrm{NO}}^{\prime}$ & R5 & -0.251 & 0.3153 \\
\hline$C_{A, N O}$ & $\mathrm{FEV}_{1}: \mathrm{VC}$ & -0.094 & 0.7108 \\
\hline $\mathrm{C}_{\mathrm{A}, \mathrm{NO}}$ & R5 & 0.267 & 0.2834 \\
\hline
\end{tabular}

$\mathrm{FEV}_{1}$, forced expiratory volume in $1 \mathrm{~s} ; \mathrm{VC}$, vital capacity.

Table 4. Correlations between $\mathrm{F}_{\mathrm{eNO}}$ and pulmonary blood flow measurements

\begin{tabular}{|c|c|c|c|}
\hline \multicolumn{4}{|c|}{ Sickle cell disease children } \\
\hline & & $r_{\mathrm{s}}$ & $P$ \\
\hline$Q_{\text {pulm }}$ & $\mathrm{Fe}_{\mathrm{NO}, 50 / \mathrm{s}}$ & 0.496 & 0.036 \\
\hline $\mathrm{QI}_{\text {pulm }}$ & $\mathrm{Fe}_{\mathrm{NO}, 501 / \mathrm{s}}$ & 0.591 & 0.0112 \\
\hline $\mathrm{Q}_{\text {pulm }}$ & $J^{\prime}{ }_{a w, N O}$ & 0.328 & 0.1834 \\
\hline $\mathrm{QI}_{\text {pulm }}$ & $\mathrm{J}_{\mathrm{aw}, \mathrm{NO}}^{\prime}$ & 0.290 & 0.2423 \\
\hline$Q_{\text {pulm }}$ & $C_{A, N O}$ & 0.500 & 0.0343 \\
\hline $\mathrm{QI}_{\text {pulm }}$ & $C_{A, N O}$ & 0.742 & 0.0006 \\
\hline $\mathrm{Q}_{\text {pulm }}$ & $\mathrm{V}_{\mathrm{A}, \mathrm{NO}}^{\prime}$ & 0.761 & 0.0002 \\
\hline $\mathrm{QI}_{\text {pulm }}$ & $\mathrm{V}_{\mathrm{A}, \mathrm{NO}}^{\prime}$ & 0.806 & $<0.0001$ \\
\hline \multicolumn{4}{|c|}{ Controls } \\
\hline $\mathrm{Q}_{\text {pulm }}$ & $\mathrm{Fe}_{\mathrm{NO}, 50 / / \mathrm{s}}$ & -0.1030 & 0.7042 \\
\hline $\mathrm{QI}_{\text {pulm }}$ & $\mathrm{Fe}_{\mathrm{NO}, 50 / / \mathrm{s}}$ & -0.1235 & 0.6485 \\
\hline $\mathrm{Q}_{\text {pulm }}$ & $\mathrm{J}_{\mathrm{aw}, \mathrm{NO}}^{\prime}$ & -0.1511 & 0.5631 \\
\hline $\mathrm{QI}_{\text {pulm }}$ & $\mathrm{J}_{\mathrm{aw}, \mathrm{NO}}^{\prime}$ & -0.1680 & 0.5192 \\
\hline $\mathrm{Q}_{\text {pulm }}$ & $\mathrm{C}_{\mathrm{A}, \mathrm{NO}}$ & 0.1804 & 0.4885 \\
\hline $\mathrm{QI}_{\text {pulm }}$ & $C_{A, N O}$ & 0.0233 & 0.9293 \\
\hline $\mathrm{Q}_{\text {pulm }}$ & $\mathrm{V}_{\mathrm{A}, \mathrm{NO}}^{\prime}$ & 0.4256 & 0.0886 \\
\hline $\mathrm{QI}_{\text {pulm }}$ & $\mathrm{V}_{\mathrm{A}, \mathrm{NO}}^{\prime}$ & 0.1936 & 0.4550 \\
\hline
\end{tabular}

nitric oxide flux did not differ from that of ethnic-matched controls. Alveolar production and NO concentration were correlated with effective pulmonary blood flow in the SCD group but not in the controls, suggesting a link between alveolar NO production and a hyperdynamic circulation. Our results differ from those of Radhakrishnan et al. (14) who found that airway NO flux and exhaled $\mathrm{NO}$ at a flow of $50 \mathrm{ml} / \mathrm{s}$ but not alveolar NO production was elevated in SCD patients. Those differences may be due to a number of factors. All our controls

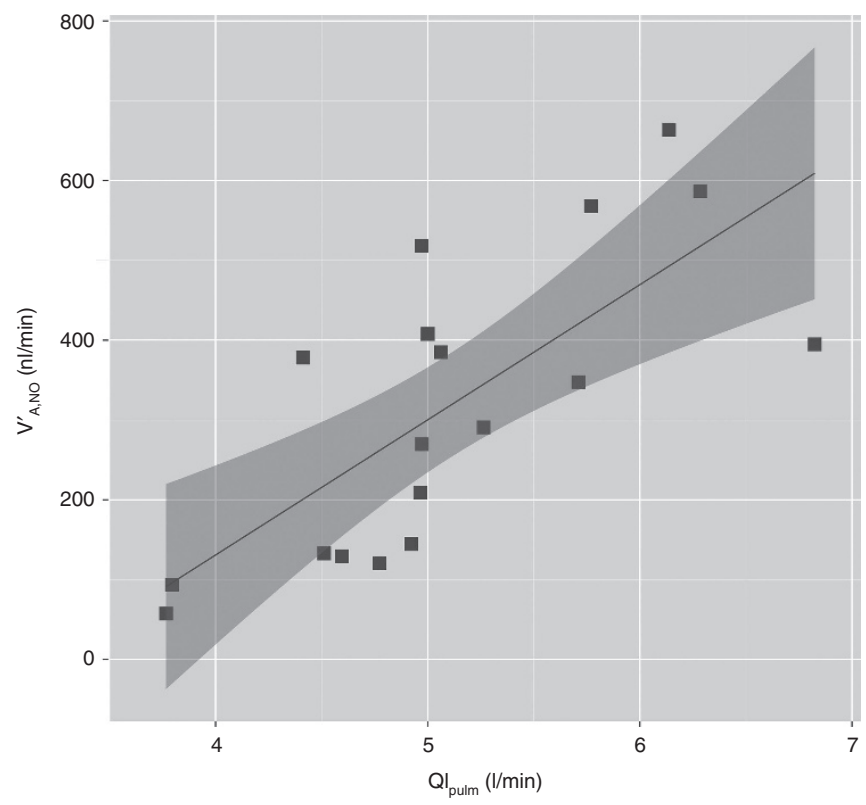

Figure 1. Alveolar nitric oxide production and the pulmonary blood flow index in sickle cell disease children ( $\square$ ). The line represents the leastsquare linear regression best fit; the shaded areas are the $95 \%$ confidence interval for the fit.

and SCD patients were of African or Caribbean ethnic origin, whereas Radhakrishnan recruited controls of various ethnicities, the majority of whom were Caucasian. In adults with $\mathrm{SCD}$, Girgis et al. (11) reported a reduction in $\mathrm{F}_{\mathrm{eNO}} 50 \mathrm{ml} / \mathrm{s}$ but used a predominantly Caucasian control group (comprising 9 African-American, 1 Asian, and 20 Caucasian subjects) (11).

Our results contrast with those from patients with cystic fibrosis and primary ciliary dyskinesia in whom airway NO is reduced compared to controls and the reduction in exhaled NO linked to more severe airway obstruction $(23,24)$. In this study, we found no significant correlations between $\mathrm{F}_{\mathrm{eNO}}$ indices and R5 or $\mathrm{FEV}_{1}: \mathrm{VC}$. A larger study (13) reported, as we now do, no difference in $\mathrm{F}_{\text {eNO50 m/s }}$ when 50 SCD children were compared to 50 ethnic-matched controls. Furthermore, airflow obstruction, as evidenced by a reduced FEV:VC was not associated with increased methacholine sensitivity or elevated $\mathrm{F}_{\mathrm{eNO}}$ (13). Those results (13) led the authors to hypothesize that sickling within the bronchial circulation may lead to airway ischemia and mucosal injury with the subsequent development of fibrosis and progressive airway obstruction. Recent studies have suggested that airflow obstruction seen in SCD at least in certain patients may reflect increased pulmonary capillary blood volume rather than asthma $(9,10)$.

To the best of our knowledge, this study is the first to assess the relationship between pulmonary hemodynamics, $\mathrm{F}_{\mathrm{eNO}}$, maximal airway NO flux, and alveolar NO concentration/ production in children with SCD. Our findings that alveolar NO production and concentration were correlated with effective pulmonary blood flow and alveolar NO production was elevated in the SCD group, despite a reduced $\mathrm{D}_{\mathrm{L}} \mathrm{NO}$ suggest that the elevated alveolar NO production was associated with a hyperdynamic circulation in SCD patients. In patients with 
liver cirrhosis and hepatopulmonary syndrome, alveolar NO concentration and the rate of alveolar $\mathrm{NO}$ production were elevated compared to healthy controls (15) and positively correlated with cardiac index (cardiac output normalized for body surface area) measured during right-heart catheterization. $\mathrm{F}_{\mathrm{eNO}}$ was also elevated in patients with an atrial septal defect (16); in addition, both pulmonary blood flow, exhaled NO concentration and plasma nitrate levels fell significantly in children and adults after surgical repair of the atrial septal defect. Although a different method for $\mathrm{NO}$ measurement was used, the $\mathrm{F}_{\text {eNO }}$ concentrations before atrial septal defect closure were similar to the alveolar NO production levels observed in this study. We have demonstrated a significant correlation between effective pulmonary blood flow and the pulmonary blood flow index and alveolar NO production. We, therefore, suggest that previously reported elevated $\mathrm{F}_{\mathrm{eNO}}$ levels in SCD children (14) may be due to an increase in alveolar nitric oxide production.

This study has strengths and some limitations. Strength of this study was the use of multiple-flow exhaled NO measurements, which enabled the maximal airway NO flux and alveolar $\mathrm{NO}$ concentration to be assessed. We also measured $\mathrm{D}_{\mathrm{L}} \mathrm{NO}$ and were therefore able to demonstrate increased alveolar NO production. We used ethnic-specific reference values for spirometric results. Although static lung volume and impulse oscillometry results were related to reference ranges derived from Caucasian subjects, the two groups were matched for ethnic origin and the same reference ranges were used in both groups, thus the comparisons between them were valid. All of the SCD children and the controls were African or Caribbean, thereby avoiding confounding from ethnic differences in exhaled NO (20-22). It should also be noted that the sample size was relatively small in this study, which may have limited our ability to detect subtle differences between the SCD and control groups. Nevertheless, highly significant differences were observed for exhaled NO and lung function results. We used a noninvasive method to measure pulmonary blood flow rather than pulmonary artery catheterization or measurements derived from CT pulmonary angiography. The method and device we used has been previously validated in children (25) and does not involve exposure to ionizing radiation, a consideration particularly pertinent when testing control children.

Airway NO flux did not differ between the SCD children and ethnic-matched controls and was not related to the airflow obstruction demonstrated in the SCD children. Those results suggest that airway obstruction at least in certain SCD children is not due to asthma.

\section{METHODS \\ Study Design}

African-Caribbean children with SCD (homozygous for sickle cell hemoglobin) were recruited. Ethnic matched children, who were either siblings of the SCD children or from local schools, were recruited as controls. The controls were age matched to the SCD years such that their age was within 2 y of the SCD children. Only children over $7 \mathrm{y}$ of age were recruited as they were likely to be able to complete all the lung function tests.

The study was conducted in the Amanda Smith Unit at King's College Hospital. No child underwent testing within 2 wk of an upper respiratory tract infection or an SCD child within a month of suffering a vaso-occlusive crisis. A history was taken of past and current respiratory symptoms and medication for respiratory problems. Standing height was measured using a wall-mounted stadiometer (Holtain, Crymych, Dyfed, UK), and weight using electronic weighing scales (Seca, Birmingham, UK). This study was conducted in accordance with the amended Declaration of Helsinki. The study was approved by the King's College Hospital Research Ethics Committee (approval number (08/H0808/29) and parents gave informed written consent for their child to take part.

\section{Lung Function Measurements}

Subjects were assessed while wearing a nose-clip and breathing through a mouthpiece. Respiratory system resistance at a frequency of $5 \mathrm{~Hz}\left(\mathrm{R}_{5}\right)$ was measured during a 90 s period of tidal breathing using impulse oscillometry (IOS, Jaeger Masterscreen IOS, Carefusion, Basingstoke UK). The results were expressed as the percent predicted for height (26). The mean of two measurements within $10 \%$ of each other was reported. IOS was performed first to avoid changes in bronchial smooth muscle tone caused by deep inspiration. Exhaled NO was measured before the remaining lung function tests were performed as recent forced expiration can influence $\mathrm{F}_{\mathrm{eNO}}$.

Spirometry, static lung volumes using whole-body plethysmography and gas transfer for carbon monoxide were assessed according to American Thoracic Society/European Thoracic Society criteria (27-29). Forced expiratory volume in $1 \mathrm{~s}\left(\mathrm{FEV}_{1}\right), \mathrm{VC}$, mean maximum expiratory flow $\left(\mathrm{FEF}_{25-27}\right)$, TLC, residual volume, transfer factor for carbon monoxide (DLCO), and transfer coefficient $\left(\mathrm{K}_{\mathrm{CO}}\right)$ were assessed and the results expressed as the percent predicted for height $(30,31)$. Ethnic-specific reference equations were not available for static lung volumes or gas transfer; therefore the predicted values were adjusted using appropriate correction factors (32). The transfer factor for nitric oxide (DLNO) was obtained by the addition of 40 ppm NO to the inspired gas mixture prior to commencing the single-breath DLCO measurement (33). Measurements were performed using a pneumotachograph-based system (Jaeger Masterscreen PFT, Carefusion, Basingstoke, UK). Patients were diagnosed with a restrictive abnormality if their TLC was less than the lower limit of normal with a normal $\mathrm{FEV}_{1}: \mathrm{VC}$, an obstructive abnormality if their $\mathrm{FEV}_{1}: \mathrm{VC}$ was less than lower limit of normal and a mixed pattern if both TLC and $\mathrm{FEV}_{1}$ :VC were less than the lower limit of normal (34).

\section{$\mathrm{F}_{\text {eNo }}$ Measurements}

Exhaled nitric oxide was assessed according to American Thoracic Society/European Thoracic Society criteria (35). Exhalation was performed at target flows of 50,100,150, and $350 \mathrm{ml} / \mathrm{s}$ against a fixed resistance to maintain velo-pharyngeal closure. Expiratory flow was recorded using an integral flow meter during each maneuvre and used to calculate NO output. Linear regression of the NO output vs. flow was performed to derive the total maximal airway NO flux $\left(\mathrm{J}_{\mathrm{aw}, \mathrm{NO}}^{\prime}\right)(\mathrm{nl} / \mathrm{min})$ and the alveolar $\mathrm{NO}$ concentration $\left(\mathrm{C}_{\mathrm{A}, \mathrm{NO}}\right)(\mathrm{ppb})$ using the model of Condorelli et al. (19) which adjusts for possible contamination of the alveolar region by back-diffusion of NO from the airway compartment. A commercial online $\mathrm{NO}$ analyser system (Hypair $\mathrm{F}_{\mathrm{eNO}}$, Medisoft Cardio-respiratory instrumentation, Sorinnes, Belgium) was used for all measurements. All exhaled NO measurements were performed without a noseclip. The equation of Perillo et al. (36) was used to derive the rate of alveolar NO production $\left(\mathrm{V}_{\mathrm{A}, \mathrm{NO}}\right)$ (nl/min) as follows:

$$
\mathrm{V}_{\mathrm{A}, \mathrm{NO}}=\text { DLNO. } \mathrm{C}_{\mathrm{A}, \mathrm{NO}}\left(\mathrm{P}_{\mathrm{atm}}-\mathrm{P}_{\mathrm{H} 2 \mathrm{O}}\right) \cdot 10^{3}
$$

where $\mathrm{P}_{\mathrm{H} 2 \mathrm{O}}$ is water vapor partial pressure (assumed to be $47 \mathrm{mmHg}$ ) and $\mathrm{P}_{\text {att }}$ is the atmospheric pressure and $\mathrm{D}_{\mathrm{L}} \mathrm{NO}$ is expressed in $\mathrm{ml} /$ $\mathrm{min} / \mathrm{mHg} . \mathrm{F}_{\mathrm{eNO}}$ measurements were performed before the DLCODLNO maneuvre to avoid contamination by inspired NO in the test gas mix.

\section{Pulmonary Blood Flow Measurements}

To assess the pulmonary circulation, effective pulmonary blood flow $\left(\mathrm{Q}_{\text {pulm }}\right)$ was measured noninvasively by the inert-gas rebreathing 
method using a commercially available device (Innocor, Innovision ApS, Glamsbjerg, Denmark). The inspired gas mixture contained $0.5 \%$ nitrous oxide $\left(\mathrm{N}_{2} \mathrm{O}\right)$ and $0.1 \%$ sulfur hexafluoride $\left(\mathrm{S}_{\mathrm{F}} 6\right)$ as the soluble and insoluble components respectively (25). To adjust for body size, the pulmonary blood flow index $\left(\mathrm{QI}_{\mathrm{pum}}\right)$ was derived by dividing $\mathrm{Q}_{\mathrm{p}}$ by the predicted body surface area using the formula of Mosteller (37).

\section{Analysis}

The data were not normally distributed; therefore differences between groups were assessed using the Wilcoxon rank test. Correlations as assessed by Spearman's rank coefficient were calculated to determine the strength of relationships between airway NO flux and airflow obstruction $\left(\mathrm{FEV}: \mathrm{VC}\right.$ and $\mathrm{R}_{5}$ ) and alveolar NO production and effective pulmonary blood flow. Statistical analysis was performed using $\mathrm{R}$ software (version 3.1.1, R Foundation for Statistical Computing, Vienna, Austria).

\section{Sample Size}

Comparison of 18 children in each group allowed detection of a difference in the results equivalent to one standard deviation between the groups with $80 \%$ power at the $5 \%$ level.

\section{ACKNOWLEDGMENTS}

A.L. and A.G. designed the study; A.L. and N.A. collected the data; A.L. and A.G. analyzed the data. All authors were involved in the production of the final manuscript.

\section{STATEMENT OF FINANCIAL SUPPORT}

This research was supported by the National Institute for Health Research (NIHR) Biomedical Research Centre at Guy's and St Thomas' NHS Foundation Trust and King's College London. The views expressed are those of the author(s) and not necessarily those of the NHS, the NIHR, or the Department of Health.

Disclosure: None to declare.

\section{REFERENCES}

1. Piel FdrB, Patil AP, Howes RE, et al. Global epidemiology of sickle haemoglobin in neonates: a contemporary geostatistical model-based map and population estimates. The Lancet 2013;381:142-51.

2. Quinn CT, Rogers ZR, McCavit TL, Buchanan GR. Improved survival of children and adolescents with sickle cell disease. Blood 2010;115:3447-52.

3. Powars D, Weidman JA, Odom-Maryon T, Niland JC, Johnson C. Sickle cell chronic lung disease: prior morbidity and the risk of pulmonary failure. Medicine (Baltimore) 1988;67:66-76.

4. Koumbourlis AC, Zar HJ, Hurlet-Jensen A, Goldberg MR. Prevalence and reversibility of lower airway obstruction in children with sickle cell disease. J Pediatr 2001;138:188-92.

5. Knight-Madden JM, Forrester TS, Lewis NA, Greenough A. Asthma in children with sickle cell disease and its association with acute chest syndrome. Thorax 2005;60:206-10.

6. Boyd JH, Moinuddin A, Strunk RC, DeBaun MR. Asthma and acute chest in sickle-cell disease. Pediatr Pulmonol 2004;38:229-32.

7. Bernaudin F, Strunk RC, Kamdem A, et al. Asthma is associated with acute chest syndrome, but not with an increased rate of hospitalization for pain among children in France with sickle cell anemia: a retrospective cohort study. Haematologica 2008;93:1917-8.

8. Batra AS, Acherman RJ, Wong WY, et al. Cardiac abnormalities in children with sickle cell anemia. Am J Hematol 2002;70:306-12.

9. Wedderburn CJ, Rees D, Height S, et al. Airways obstruction and pulmonary capillary blood volume in children with sickle cell disease. Pediatr Pulmonol 2014;49:716-22.

10. Lunt A, Desai SR, Wells AU, et al. Pulmonary function, CT and echocardiographic abnormalities in sickle cell disease. Thorax 2014;69:746-51.

11. Girgis RE, Qureshi MA, Abrams J, Swerdlow P. Decreased exhaled nitric oxide in sickle cell disease: relationship with chronic lung involvement. Am J Hematol 2003;72:177-84.

12. Aslan M, Thornley-Brown D, Freeman BA. Reactive species in sickle cell disease. Ann N Y Acad Sci 2000;899:375-91.

13. Chaudry RA, Rosenthal M, Bush A, Crowley S. Reduced forced expiratory flow but not increased exhaled nitric oxide or airway responsiveness to methacholine characterises paediatric sickle cell airway disease. Thorax 2014;69:580-5.
14. Radhakrishnan DK, Bendiak GN, Mateos-Corral D, et al. Lower airway nitric oxide is increased in children with sickle cell disease. J Pediatr 2012;160:93-7.

15. Degano B, Mittaine M, Hervé $\mathrm{P}$, et al. Nitric oxide production by the alveolar compartment of the lungs in cirrhotic patients. Eur Respir J 2009;34:138-44.

16. Tworetzky W, Moore P, Bekker JM, Bristow J, Black SM, Fineman JR. Pulmonary blood flow alters nitric oxide production in patients undergoing device closure of atrial septal defects. J Am Coll Cardiol 2000;35:463-7.

17. Delclaux C, Mahut B, Zerah-Lancner F, et al. Increased nitric oxide output from alveolar origin during liver cirrhosis versus bronchial source during asthma. Am J Respir Crit Care Med 2002;165:332-7.

18. George SC, Hogman M, Permutt S, Silkoff PE. Modeling pulmonary nitric oxide exchange. J Appl Physiol (1985) 2004;96:831-9.

19. Condorelli P, Shin HW, Aledia AS, Silkoff PE, George SC. A simple technique to characterize proximal and peripheral nitric oxide exchange using constant flow exhalations and an axial diffusion model. J Appl Physiol (1985) 2007;102:417-25.

20. Sonnappa S, Bastardo CM, Stafler P, Bush A, Aurora P, Stocks J. Ethnic differences in fraction of exhaled nitric oxide and lung function in healthy young children. Chest 2011;140:1325-31.

21. Brody DJ, Zhang X, Kit BK, Dillon CF. Reference values and factors associated with exhaled nitric oxide: U.S. youth and adults. Respir Med 2013;107:1682-91.

22. Linn WS, Rappaport EB, Eckel SP, et al. Multiple-flow exhaled nitric oxide, allergy, and asthma in a population of older children. Pediatr Pulmonol 2013;48:885-96.

23. Hubert D, Aubourg F, Fauroux B, et al. Exhaled nitric oxide in cystic fibrosis: relationships with airway and lung vascular impairments. Eur Respir J 2009;34:117-24.

24. Shoemark A, Wilson R. Bronchial and peripheral airway nitric oxide in primary ciliary dyskinesia and bronchiectasis. Respir Med 2009;103: $700-6$.

25. Wiegand G, Kerst G, Baden W, Hofbeck M. Noninvasive cardiac output determination for children by the inert gas-rebreathing method. Pediatr Cardiol 2010;31:1214-8.

26. Nowowiejska B, Tomalak W, Radliński J, Siergiejko G, Latawiec W, Kaczmarski M. Transient reference values for impulse oscillometry for children aged 3-18 years. Pediatr Pulmonol 2008;43:1193-7.

27. Miller MR, Hankinson J, Brusasco V, et al.; ATS/ERS Task Force. Standardisation of spirometry. Eur Respir J 2005;26:319-38.

28. Wanger J, Clausen JL, Coates A, et al. Standardisation of the measurement of lung volumes. Eur Respir J 2005;26:511-22.

29. Macintyre N, Crapo RO, Viegi G, et al. Standardisation of the singlebreath determination of carbon monoxide uptake in the lung. Eur Respir J 2005;26:720-35.

30. Quanjer PH, Stanojevic S, Cole TJ, et al.; ERS Global Lung Function Initiative. Multi-ethnic reference values for spirometry for the 3-95-yr age range: the global lung function 2012 equations. Eur Respir J 2012;40: 1324-43.

31. Rosenthal M, Cramer D, Bain SH, Denison D, Bush A, Warner JO. Lung function in white children aged 4 to 19 years: II-Single breath analysis and plethysmography. Thorax 1993;48:803-8.

32. Kirkby J, Bonner R, Lum S, et al. Interpretation of pediatric lung function: impact of ethnicity. Pediatr Pulmonol 2013;48:20-6.

33. Moinard J, Guenard H. Determination of lung capillary blood volume and membrane diffusing capacity in patients with COLD using the NO-CO method. Eur Respir J 1990;3:318-22.

34. Pellegrino R, Viegi G, Brusasco V, et al. Interpretative strategies for lung function tests. Eur Respir J 2005;26:948-68.

35. ATS/ERS recommendations for standardized procedures for the online and offline measurement of exhaled lower respiratory nitric oxide and nasal nitric oxide, 2005. Am J Respir Crit Care Med 2005;171:912-30.

36. Perillo IB, Hyde RW, Olszowka AJ, et al. Chemiluminescent measurements of nitric oxide pulmonary diffusing capacity and alveolar production in humans. J Appl Physiol (1985) 2001;91:1931-40.

37. Mosteller RD. Simplified calculation of body-surface area. N Engl J Med 1987;317:1098 